\title{
Experimental protocol to repel opossums (Didelphis marsupialis) through an artisanal odor repellent device
}

\author{
Protocolo experimental para ahuyentar zarigüeyas (Didelphis marsupialis) mediante un dispositivo \\ artesanal de olor repelente
}

\begin{abstract}
Protocolo experimental para repelir gambás (idelphis marsupialis) por meio de um dispositivo artesanal de odor repelente
\end{abstract}

\author{
Karen N Rodríguez $^{1}$ (D); Diana R Aguirre ${ }^{1}$ (D); Claudia P Ceballos ${ }^{2 *}$ (D). \\ ${ }^{1}$ Private practice, Medellin, Colombia. \\ ${ }^{2}$ GAMMA Research Group, Escuela de Medicina Veterinaria, Facultad de Ciencias Agrarias, Universidad de Antioquia.
}

To cite this article:

Rodríguez KN, Aguirre DR, Ceballos CP. Experimental protocol to repel opossums (Didelphis marsupialis) through an artisanal odor repellent device. Rev Colomb Cienc Pecu 2022; 35(4): 205-216. DOI: https://doi.org/10.17533/udea.rccp.v35n4a01

\begin{abstract}
Background: The human-opossum (Didelphis marsupialis) conflict has increased during the last decades mainly due to natural habitat loss, and mediated by generalist and opportunistic habits of opossums. A potential solution to reduce this conflict is to discourage the presence of opossums in human settlements without affecting the welfare of either part. Objective: To develop an artisanal odor device and test three chemical substances (citronella, ammonia, and creolin) for their separate effectiveness to drive away opossums. Methods: We first attracted local opossums using fruits or canned sardines as bait in an urban natural park ( $n=2$ sites) and a peri-urban forest reserve ( $n=4$ sites), both located in the Municipality of Envigado, Province of Antioquia, Colombia. Then we installed odor devices containing one of the three chemicals on each site and let them there during two weeks. The test was repeated with each of the chemicals in all sites. The number of opossum visits per night was recorded daily using camera-traps with bait and bait+chemical. Results: We found that ammonia and creolin were associated to fewer opossum visits per night. Citronella did not reduce the presence of opossums. In addition, the number of opossums/per night was higher in the urban park compared with the forest reserve. Conclusion: We suggest to further test the repellent effect of ammonia and creolin on real human-opossum conflict scenarios; however, caution is warranted given their irritant, flammable, and corrosive properties.
\end{abstract}

Keywords: aversive conditioning; deterrent; Didelphis marsupialis; human-opossum conflict; odors; opossums; repellents; urban wildlife; wildlife; wildlife management.

Received: September 27, 2021; Accepted: December 8, 2021

*Corresponding author. Calle 70 No. 52-21, Medellín, Colombia. Email:claudiap.ceballos@udea.edu.co 


\section{Resumen}

Antecedentes: El conflicto entre humanos y zarigüeyas (Didelphis marsupialis) se ha acrecentado en las últimas décadas debido, principalmente, a la pérdida de hábitats naturales y mediado por los hábitos generalistas y oportunistas de las zarigüeyas. Una posible alternativa de solución a este conflicto es desalentar la presencia de zarigüeyas en áreas habitadas por humanos, sin afectar el bienestar de ninguna de las dos partes. Objetivo: Desarrollar un dispositivo artesanal de olor y probarlo con tres sustancias químicas de manera separada (citronela, amoniaco, y creolina) probando su efectividad para ahuyentar a las zarigüeyas. Métodos: Inicialmente cebamos con frutas o sardinas enlatadas para atraer las zarigüeyas locales en un parque natural urbano ( $\mathrm{n}=2$ sitios) y una reserva forestal peri-urbana ( $\mathrm{n}=4$ sitios), ambas en el Municipio de Envigado, Departamento de Antioquia, Colombia. Posteriormente, instalamos el dispositivo con uno de los tres químicos en cada sitio durante dos semanas. El test se repitió con los tres químicos en todos los sitios. El número de zarigüeyas/noche se registró diariamente usando cámaras-trampa con cebo, y con cebo+químico. Resultados: El amoníaco y la creolina se asociaron con un menor número de visitas de zarigüeya/noche. Por otro lado, cuando se adicionó citronela, el número de visitas no disminuyó. Adicionalmente, el número de zarigüeyas/noche registradas en el parque urbano fue mayor con respecto a la reserva forestal peri-urbana. Conclusión: El amoniaco y la creolina tienen efecto ahuyentador de zarigüeyas. Sugerimos evaluar su efecto en ambientes de conflicto real humanos-zarigüeyas, tomando precauciones durante su manipulación dadas sus propiedades irritantes, corrosivas e inflamables.

Palabras clave: condicionamiento aversivo; conflicto humano-zarigüeya; Didelphis marsupialis; disuasores; fauna silvestre; fauna silvestre urbana; manejo de fauna silvestre; olores, repelentes; zarigüeyas.

\section{Resumo}

Antecedentes: O conflito humano-gambá (Didelphis marsupialis) tem aumentado durante as últimas décadas devido principalmente à perda do habitat natural e tem sido mediado pelos hábitos generalistas e oportunistas do gambá. uma solução potencial para reduzir esse conflito é desencorajar a presença de gambás em assentamentos humanos sem afetar o bem-estar de ambas as partes. Objetivo: Desenvolver um dispositivo artesanal de odor com três diferentes produtos químicos: citronela, amônia e creolina, e testamos sua eficácia para afastar gambás. Métodos: Inicialmente atraímos gambás locais usando frutas ou sardinhas em lata como isca em duas áreas, um parque natural urbano ( $\mathrm{n}=2$ locais) e uma reserva florestal periurbana ( $n=4$ locais), ambos em Envigado, Antioquia, Colômbia. Posteriormente, instalamos o dispositivo de odor usando um dos três produtos químicos em cada local durante duas semanas. O ciclo foi repetido com todos os três produtos químicos em todos os locais. O número de gambás/noite foi registrado diariamente usando câmera-armadilhas com isca e isca+produto químico. Resultados: Verificamos que a amônia e a creolina estiveram associadas ao menor número de gambás/noite, mesmo quando os locais ainda estavam iscados, e que a citronela não diminuiu a presença de gambás/noite quando adicionada aos locais iscados. Além disso, o número de gambás/noite foi maior no parque urbano em relação à reserva florestal. Conclusão: Sugerimos avaliar o efeito repelente da amônia e da creolina em cenários reais de conflito entre humanos e gambás; no entanto, deve-se ter cuidado devido às suas propriedades irritantes, inflamáveis e corrosivas.

Palavras-chave: condicionamento aversivo; conflito homem-gambá; Didelphis marsupialis; dissuasivo; gambás; manejo da vida selvagem; odores, repelentes; vida selvagem; vida selvagem urbana. 


\section{Introduction}

Human-wildlife conflicts is a state of hostility or fight in which either one part has an adverse effect on the other (Redpath et al., 2015). The human-opossum conflict is a current concern in metropolitan areas of the Antioquia province (Colombia) (Delgado, 2007) as reported by Fundación Zarigüeya (FUNDZAR), a Colombian NGO aimed to increase welfare standards of opossums. From 2018 to 2020 FUNDZAR received 3,008 opossum-related calls from citizens asking for advice. From this total, $62.6 \%$ were road-kills, $14.9 \%$ were dog or cat attacks, 10.1\% were hard-objects hitting, and 9.7\% orphaned opossums (F. Flórez FUNDZAR director; personal communication, June 15, 2021).

The common opossum (Didelphis marsupialis, Didelphidae) is a neotropical mammal distributed from Mexico to Argentina. Opossums have a highly unrestricted and opportunistic diet, are skillful in arboreal and terrestrial environments, and have high reproductive potential of up to 10 youngsters twice a year (McManus, 1970; Flórez-Oliveros and VivasSerna, 2020). Due to these characteristics, opossums are ecologically successful in a wide range of habitats (McManus, 1970; Sunquist et al., 1987; Vaughan and Hawkins, 1999). In addition, deforestation in Antioquia is high and it is associated to pasture establishment, urban expansion, and wildland fires (GonzálezCaro and Vásquez, 2017). These conditions are difficult to manage, and the human-opossum conflict may worsen (Rueda et al., 2013) if no practical solutions are implemented to discourage their encounters.

Several repellents have been proposed to mitigate wildlife-human conflicts, including acoustic, visual, odor, electric, and irritant methods (Mason, 1998; Gerisoli and Pereira, 2020). Electrical fencing, trip alarms, and warning calls have also been used. However, they are expensive and not viable in the long term (O'Connell-Rodwell et al., 2000). Other methods, such as burning animal feces with ground chillies to produce a noxious smoke, are more effective and inexpensive (Osborn and Parker, 2002). Plant oils are also used as olfactory repellents, and wolf urine as antipredator to repel deer; however, these were not effective perhaps due to rapid habituation (Elmeros et al., 2011).

To our knowledge, no odor repellents have been systematically tested on opossums; thus, herein we tested citronella, ammonia, and creolin, as potential odor repellents. We set camera-traps to estimate the frequency of opossum visits to the study sites in two localities.

\section{Materials and Methods}

\section{Ethical considerations}

This study was approved by the Committee on Ethics in Animal Research of the Universidad de Antioquia, Colombia (Act 114, December $5^{\text {th }}$, 2017).

\section{Study sites}

We chose a total of six sites in two localities in the Municipality of Envigado, Province of Antioquia (Colombia), to test the effectiveness of three chemicals as odor repellents for opossums. Four sites were located at a natural forest named La Morena Ecologic Reserve (Morena 1, 2, 3, 4), and two sites at the urban park La Heliodora (Heliodora 1, 2). Morena is a 37 -hectare periurban forest located in the rural area named El Escobero at 2,200 m.a.s.1., while Heliodora is a 24-hectare park at 1,575 m.a.s.l. (Alcaldía de Envigado, 2016). We chose four sites in Morena and only two in Heliodora because the latter is more visited by the local community, thus there was a higher risk of losing the equipment. We installed one camera-trap per site (three Bushnell Trophy Cam Essential 12mp, two Bushnell Trophy Cam Hd Aggresso 14mp, and a Cuddeback 20mp IR plus) which was set to record 20 -second videos with 10 -second intervals, and high sensitivity to movement. The camera-traps recorded the presence of opossums and other species from April to October 2018. The total number of sampling days slightly varied on the sites due to rough environmental conditions. 


\section{Chemicals and odor devices}

Three chemicals were used in the study: citronella, ammonia, and creolin. Citronella (CAS registry number 8000-29-1) is a waterinsoluble oil extracted from an aromatic plant (density $0.85 \mathrm{~g} / \mathrm{mL}$ ). It has a light-yellow color, citric smell, and is efficient as insect repellent (Sharma et al., 2019). Ammonia or ammonium hydroxide (CAS registry number 7664-41-7) is a solution of NH3 in water (24-28\%), colorless and highly irritant. Citronella and ammonia were bought from local chemical retail stores, e.g., Quimicos JM S.A., and Protokimica. Creolin (CAS registry number 12751-04-1) is a natural over-the-counter disinfectant mainly composed of phenol (17\%). It is commonly used as antiseptic to clean wounds, bathrooms, and barns at low concentrations, although in higher concentrations can cause severe toxicity (Vearrier et al., 2015). This chemical was purchased from different labs with the same phenol concentration (e.g., Fenolgan ${ }^{\circledR}$ produced by Farmagan Colombia S.A.S. laboratory, or -Específico ${ }^{\circledR}$ produced by Rotam-Vet Colombia).

To contain the chemicals, six devices were prepared using inexpensive materials. They consisted of five-gallon plastic containers (40 $\mathrm{cm}$ diameter) with four 2-cm holes below the lid. Then a polyurethane foam strip $(100 \times 4 \times$ $4 \mathrm{~cm}$ ) was wrapped inside the container and the liquid chemical was poured to cover the foam so its gases spread out of the container through the holes.

\section{Experimental design}

All sites were initially baited with fruit (ripe mango or plantain, wrapped in a piece of veil and hanging from a tree) or canned sardines to habituate the resident opossums for approximately three to four months. Immediately afterwards, the chemical devices were installed besides the bait, one device per site for two weeks. A new cycle started by removing the device and baiting again for two weeks, and then adding a different chemical for two weeks again. Each of these cycles were repeated on each site only changing the chemical until all three chemicals were tested on each site. Citronella was tested first, then was ammonia, and lastly creolin (Table 1). The cameras permanently recorded the activity at each site, and every 14 days they were checked to retrieve the videos and identify the wildlife species visiting the sites. Site Morena 1 was chosen as a control site and the device installed there had no chemical inside. The control site was used to test that the container itself did not affect the frequency of opossum visits.

Table 1. Experimental design of the study indicating the treatment (only bait or bait + chemical) used in each site.

\begin{tabular}{|c|c|c|c|c|c|c|}
\hline \multirow{2}{*}{$\begin{array}{c}\begin{array}{c}\text { Site } \\
\text { (bait) }\end{array} \\
\text { Morena 1= } \\
\text { Control site } \\
\text { (fruit) }\end{array}$} & \multicolumn{6}{|c|}{$\begin{array}{c}\text { Treatment } \\
\text { (days of each cycle) }\end{array}$} \\
\hline & bait (92 d) & $\begin{array}{c}\text { bait+empty } \\
\text { container }(14 \mathrm{~d})\end{array}$ & bait (20 d) & $\begin{array}{l}\text { bait+empty } \\
\text { container } \\
\text { (16 d) }\end{array}$ & bait (13 d) & $\begin{array}{l}\text { bait+creolin } \\
\quad(14 \mathrm{~d})\end{array}$ \\
\hline $\begin{array}{l}\text { Heliodora } 1 \\
\text { (fruit) }\end{array}$ & bait (95 d) & $\begin{array}{l}\text { bait+citronella } \\
\qquad(14 \mathrm{~d})\end{array}$ & bait (20 d) & $\begin{array}{l}\text { bait+ammonia } \\
\qquad(16 \mathrm{~d})\end{array}$ & bait (13 d) & $\begin{array}{l}\text { bait }+ \text { creolin } \\
\quad(14 \mathrm{~d})\end{array}$ \\
\hline $\begin{array}{l}\text { Heliodora } 2 \\
\text { (sardines) }\end{array}$ & bait (95 d) & $\begin{array}{l}\text { bait }+ \text { citronella } \\
\qquad(14 \mathrm{~d})\end{array}$ & bait (20 d) & $\begin{array}{l}\text { bait+ammonia } \\
\qquad(16 \mathrm{~d})\end{array}$ & bait (13 d) & $\begin{array}{c}\text { bait+creolin } \\
(14 \mathrm{~d})\end{array}$ \\
\hline $\begin{array}{l}\text { Morena } 2 \\
\text { (fruit) }\end{array}$ & bait (117 d) & $\begin{array}{l}\text { bait }+ \text { citronella } \\
\qquad(14 \mathrm{~d})\end{array}$ & bait (20 d) & $\begin{array}{l}\text { bait+ammonia } \\
\qquad(16 \mathrm{~d})\end{array}$ & bait (13 d) & $\begin{array}{l}\text { bait+creolin } \\
(14 \mathrm{~d})\end{array}$ \\
\hline $\begin{array}{l}\text { Morena } 3 \\
\quad \text { (fruit) }\end{array}$ & bait (103 d) & $\begin{array}{l}\text { bait+citronella } \\
\quad(14 \mathrm{~d})\end{array}$ & bait (20 d) & $\begin{array}{l}\text { bait+ammonia } \\
\qquad(16 \mathrm{~d})\end{array}$ & bait (13 d) & $\begin{array}{l}\text { bait+creolin } \\
(14 \mathrm{~d})\end{array}$ \\
\hline $\begin{array}{l}\text { Morena } 4 \\
\text { (sardines) }\end{array}$ & bait (113 d) & $\begin{array}{l}\text { bait+citronella } \\
\qquad(14 \mathrm{~d})\end{array}$ & bait (20 d) & $\begin{array}{l}\text { bait+ammonia } \\
\qquad(16 \mathrm{~d})\end{array}$ & bait (13 d) & $\begin{array}{l}\text { bait }+ \text { creolin } \\
\text { (14 d) }\end{array}$ \\
\hline
\end{tabular}

The number in parenthesis indicates the duration of each cycle (d: days). 


\section{Data analysis}

There were nights with several videos obtained at different times; however, it was not possible to differentiate whether the opossum was the same or a different individual as many videos were recorded within $60 \mathrm{~min}$ at the same site. Thus, to be conservative, we counted only the number of nights with opossum records (and nights without opossum records) regardless of the nightly number of videos obtained. The capture success was calculated by dividing the number of nights that opossums were recorded by the number of camera trap-nights and multiplying the result by 100 (Srbek-Araujo and Chiarello 2013). Fisher's exact tests of independence were used to test the null hypothesis that the proportion of opossums/night (number of nights with opossum/number of nights without opossums) without the chemical (citronella, ammonia, or creolin) is not different than the proportion of opossums with the chemical. This null hypothesis would indicate that the chemical did not repel the opossums. P-values below 0.05 were considered significant to reject the Ho and accept the alternative hypothesis that the proportions varied (i.e., that the chemical repelled the opossums). Fisher's exact test is more accurate than the Chi-square test when the expected numbers are small (i.e., when sample size is less than 20 in a $2 \times 2$ contingency table; McCrum-Gardner 2008). Fisher's exact tests were done using the function fisher.test in package stats version 4.0.2 in R environment.

\section{Results}

\section{Repellent effectiveness}

We compared the proportion of opossums recorded (nights with opossums/nights without opossums) using bait alone vs. bait plus one of the three chemicals expected to drive the opossums away. The proportions were statistically different at some sites with ammonia and creolin, but not with citronella (Table 2). Specifically, there were less opossums when ammonia was added at Heliodora 2 and overall (counting all sites together; $p<0.0008$ and $p<0.0007$, respectively); and there were less opossums when creolin was added at Morena 4 and overall $(p<0.0003$ and $p<0.0113$, respectively). Citronella showed no effect on the presence or absence of opossums at either of the sites tested nor overall $(\mathrm{p}>0.05$ all sites and overall).

The results were significant in spite that other factors also affected the proportion of opossums recorded (i.e., the sampling site and the bait used). There were more opossums at the urban park ( $\mathrm{n}=43$, in two sites) than at the peri-urban forest ( $\mathrm{n}=17$, in three sites) when bait alone was used $(p<0.0001)$. Also, overall, there were 38\% more opossums recorded when sardines were used as bait (21 opossums/187 nights) compared to fruits (14 opossums/331 nights; $p<0.007$ ).

\section{Nocturnal activity of opossums}

Although the chemical devices were let in place from May to October 2018, the cameras stayed in place longer, until February 2019. In this way we obtained a total of 244 videos recording opossums at five sites (Heliodora 1 and 2, and Morena 1,2 and 4). The activity peak of opossums was recorded by midnight in both the urban park and the peri-urban forest, starting by 18:00 hours and ending by 8:00 (Figure 1). Although there seems to be a tendency to start the activity early in the afternoon and finish late in the morning at the urban site, we found no statistical difference in the frequency distributions between both sites $(\mathrm{p}=0.297)$.

\section{Richness of wildlife species}

We recorded a higher richness of species at the peri-urban forest than at the urban park after pooling the results from all sites within each one. This is, we recorded nine different species of mammals of medium and large body size (including Dasypus novemcinctus, Potos flavus, Eira barbara, Mustela frenata, Cerdocyon thous, and Herpailurus yagouaroundi), and nine birds at Morena. At the urban park we recorded three mammals of small and medium body size (Notosciurus granatensis and Cerdocyon thous) and three birds (Table 3). 
Table 2. Number of days with opossums/number of days without opossums, discriminated by site and treatment (bait or bait+chemical).

\begin{tabular}{|c|c|c|c|c|c|c|c|c|c|c|c|c|}
\hline Site & Bait & $\begin{array}{c}\text { Bait }+ \\
\text { Citronella } \\
\end{array}$ & $\mathbf{p}$ & Interpretation & Bait & $\begin{array}{c}\text { Bait }+ \\
\text { Ammonia }\end{array}$ & $\mathbf{p}$ & Interpretation & Bait & $\begin{array}{c}\text { Bait + } \\
\text { Creolin }\end{array}$ & $\mathbf{p}$ & Interpretation \\
\hline Control site & $8 / 109$ & $0 / 14$ & 0.599 & $\begin{array}{c}\text { No effect } \\
\text { (as expected) }\end{array}$ & $1 / 19$ & $0 / 16$ & 1 & $\begin{array}{c}\text { No effect } \\
\text { (as expected) }\end{array}$ & $1 / 12$ & $0 / 14$ & 0.481 & $\begin{array}{c}\text { No effect } \\
\text { (as expected) }\end{array}$ \\
\hline Heliodora 1 & $10 / 85$ & $0 / 14$ & 0.355 & No effect & $3 / 17$ & $0 / 16$ & 0.238 & No effect & $1 / 12$ & $0 / 14$ & 0.481 & No effect \\
\hline Heliodora 2 & $16 / 79$ & $4 / 10$ & 0.284 & No effect & $10 / 10$ & $0 / 16$ & 0.001 & $\begin{array}{l}\text { Repellent } \\
\text { effect* }\end{array}$ & $3 / 10$ & $3 / 11$ & 1 & No effect \\
\hline Morena 2 & $4 / 113$ & $0 / 14$ & 1 & No effect & $0 / 20$ & $0 / 16$ & 1 & NA & $0 / 13$ & $0 / 14$ & 1 & NA \\
\hline Morena 3 & $0 / 133$ & $0 / 14$ & 1 & NA & $0 / 20$ & $0 / 16$ & 1 & NA & $0 / 12$ & $0 / 15$ & 1 & NA \\
\hline Morena 4 & $5 / 108$ & $0 / 14$ & 1 & No effect & $0 / 20$ & $0 / 16$ & 1 & NA & $8 / 4$ & $0 / 15$ & 0.000 & $\begin{array}{l}\text { Repellent } \\
\text { effect }\end{array}$ \\
\hline $\begin{array}{c}\text { Overall } \\
\text { (excludes } \\
\text { control site) }\end{array}$ & $35 / 518$ & $4 / 66$ & 1 & No effect & $13 / 87$ & $0 / 80$ & 0.001 & $\begin{array}{l}\text { Repellent } \\
\text { effect }\end{array}$ & $12 / 51$ & $3 / 69$ & 0.011 & $\begin{array}{c}\text { Repellent } \\
\text { effect }\end{array}$ \\
\hline
\end{tabular}

Bold $\mathbf{p}$ values reject the null hypothesis and suggests the chemical had a repellent effect, e.g.: * Ammonia decreased the number of days with opossums (from 10 to

0 ) and increased the number of days without opossums (from 10 to 16). NA = not possible to test the potential repelling effect of the chemical because there were no opossums to repel. 


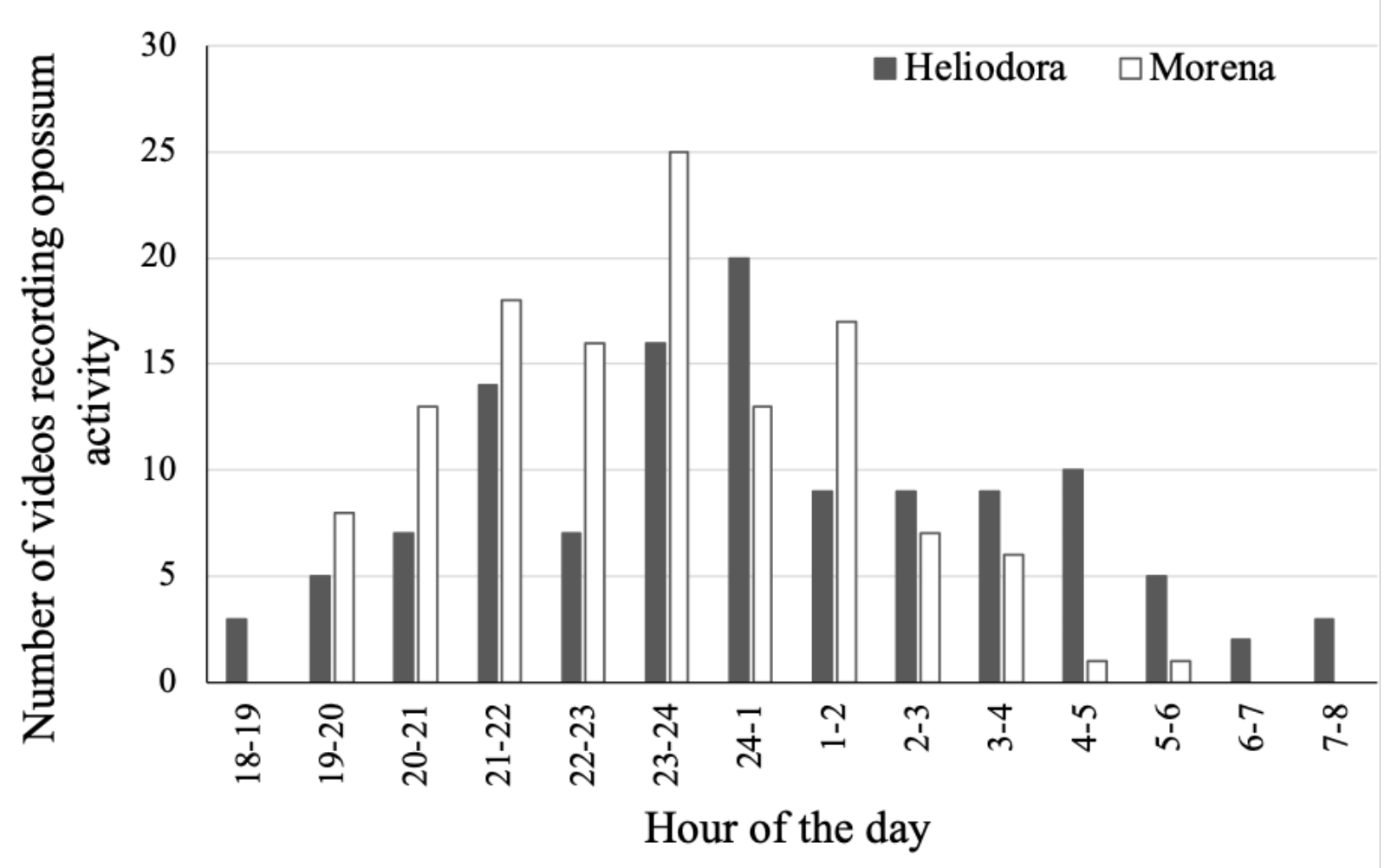

Figure 1. Nocturnal activity of opossums recorded at Heliodora urban park and Morena peri-urban forest.

Opossums were observed at all sites in Heliodora urban park and at Morena peri-urban forest (except at Morena 3), and they were always among the top three species more common at both sites. However, and as expected, opossums were more common at the urban park than at the peri-urban natural forest. This is, we recorded opossums in 42 nights using 324 camera trapnights at Heliodora (capture success $=12.96 \%$ ), compared to 30 nights using 768 camera trapnights at Morena (capture success $=3.9 \%$ ). The real number of opossums was probably higher given that we counted only the number of nights with at least one video record; not opossum records to avoid counting the same individual several times.

\section{Discussion}

When data from all sites was pooled together (regardless of the site), ammonia and creolin, but not citronella, had a significant effect to repel opossums even when bait was still available. However, in some sites (i.e., Morena 2, 3 and 4;
Table 2) no opossums, or too few, visited the site tested, making it impossible to test the chemicals at those specific sites with no opossums. Real situations of human-opossum conflict are the scenarios where these chemicals should be tested next without having to bait the area to attract opossums. Ammonia and human urine have been used successfully to deter and drive away black bears when humans encountered them in Montana (Hunt 1977), and red pepper (capsaicin) sprays in Alaska (Smith et al., 1998) as well. Furthermore, it should be considered that the effectiveness of any chemical tested may be affected by several factors, including weather conditions such as rain, relative humidity, wind temperature, variability of the opossum population density throughout the year (Mason, 1998; this study), and the bait used (this study).

Chemical repellents act in different ways, they may produce sensory irritation, semiochemical mimicry (e.g., pheromones or allomones), or digestive malaise (Brown et al., 1970; Borden, 1989; Mason, 1998). 
Ammonia gasses can be very harmful to humans; they may cause larynx blocking and lung distension and congestion (ATSDR, 2004). Creolin is similar to ammonia in that exposure to phenol, its main constituent, may be rapidly absorbed through the skin, respiratory and digestive systems, conducing to a systemic toxicity (Vearrier et al., 2015). Thus, similarly to the effect of capsaicin -the active component of chili peppers- on some mammals (Norman et al., 1992; Smith et al., 1998) the repellent efficacy of ammonia and creolin in opossums was likely sensorial; its efficacy may lie in that they produce irritation and short-term pain.

Table 3. Richness of wildlife species recorded during the study at Morena peri-urban natural forest and Heliodora urban park.

\begin{tabular}{|c|c|c|c|}
\hline Species & Local common name (in Spanish) & Observation records & Capture success \\
\hline \multicolumn{4}{|c|}{ Morena 1 (sampling nights $=194$, April 17 to Oct 27, 2018) } \\
\hline Ortalis columbiana & Guacharaca colombiana & 12 & $6.2 \%$ \\
\hline Didelphis marsupialis & Zarigüeya común & 10 & $5.2 \%$ \\
\hline Eira barbara & Hurón mayor & 4 & $2.1 \%$ \\
\hline Leptotila verreauxi & Paloma rabiblanca & 4 & $2.1 \%$ \\
\hline Cerdocyon thous & Perro de monte & 3 & $1.5 \%$ \\
\hline Notosciurus granatensis & Ardilla de cola roja & 3 & $1.5 \%$ \\
\hline Cathartes aura & Gallinazo de cabeza roja & 2 & $1.0 \%$ \\
\hline Chamaepetes goudotii & Pava maraquera & 2 & $1.0 \%$ \\
\hline Sylvilagus nicefori & Conejo de bosque & 2 & $1.0 \%$ \\
\hline Total & & 42 & \\
\hline \multicolumn{4}{|c|}{ Morena 2 (sampling nights $=194$, April 17 to Oct 27, 2018) } \\
\hline Didelphis marsupialis & Zarigüeya común & 4 & $2.1 \%$ \\
\hline Cerdocyon thous & Zorro cangrejero & 3 & $1.5 \%$ \\
\hline Notosciurus granatensis & Ardilla de cola roja & 3 & $1.5 \%$ \\
\hline Dasypus novemcinctus & Armadillo de nueve bandas & 2 & $1.0 \%$ \\
\hline Potos flavus & Perro de monte & 2 & $1.0 \%$ \\
\hline Eira barbara & Hurón mayor & 1 & $0.5 \%$ \\
\hline Leptotila verreauxi & Paloma rabiblanca & 1 & $0.5 \%$ \\
\hline Ortalis columbiana & Guacharaca colombiana & 1 & $0.5 \%$ \\
\hline Total & & 17 & \\
\hline \multicolumn{4}{|c|}{ Morena 3 (sampling nights $=190$, April 24 to October 27, 2018) } \\
\hline Leptotila verreauxi & Paloma rabiblanca & 16 & $8.4 \%$ \\
\hline Chamaepetes goudotii & Pava maraquera & 15 & $7.9 \%$ \\
\hline Notosciurus granatensis & Ardilla de cola roja & 14 & $7.4 \%$ \\
\hline Non-identified species & Not applicable & 6 & $3.2 \%$ \\
\hline Rhynchortyx cinctus & Perdiz selvática & 3 & $1.6 \%$ \\
\hline Dasypus novemcinctus & Armadillo de nueve bandas & 2 & $1.1 \%$ \\
\hline Momotus aequatorialis & Barranquero & 2 & $1.1 \%$ \\
\hline Cerdocyon thous & Zorro cangrejero & 1 & $0.5 \%$ \\
\hline Eira barbara & Hurón mayor & 1 & $0.5 \%$ \\
\hline Ortalis columbiana & Guacharaca colombiana & 1 & $0.5 \%$ \\
\hline Total & & 45 & \\
\hline
\end{tabular}




\begin{tabular}{|c|c|c|c|}
\hline \multicolumn{4}{|c|}{ Morena 4 (sampling nights $=190$, April 24 to October 27, 2018) } \\
\hline Chamaepetes goudotii & Pava maraquera & 20 & $10.5 \%$ \\
\hline Leptotila verreauxi & Paloma rabiblanca & 17 & $8.9 \%$ \\
\hline Didelphis marsupialis & Zarigüeya común & 14 & $7.4 \%$ \\
\hline Non-identified species & Not applicable & 13 & $6.8 \%$ \\
\hline Notosciurus granatensis & Ardilla de cola roja & 7 & $3.7 \%$ \\
\hline Eira Barbara & Hurón mayor & 7 & $3.7 \%$ \\
\hline Henicorhina leucophrys & Cucarachero pechigris & 5 & $2.6 \%$ \\
\hline Cerdocyon thous & Zorro cangrejero & 1 & $0.5 \%$ \\
\hline Coragyps atratus & Gallinazo & 1 & $0.5 \%$ \\
\hline Herpailurus yagouaroundi & Yaguarundí & 1 & $0.5 \%$ \\
\hline Mustela frenata & Comadreja de cola larga & 1 & $0.5 \%$ \\
\hline Potos flavus & Perro de monte & 1 & $0.5 \%$ \\
\hline Rhynchortyx cinctus & Perdiz selvática & 1 & $0.5 \%$ \\
\hline Zonotrichia capensis & Gorrión americano & 1 & $0.5 \%$ \\
\hline Total & & 90 & \\
\hline \multicolumn{4}{|c|}{ Heliodora 1 (sampling nights $=162$, May 9 to October 27,2018$)$} \\
\hline Didelphis marsupialis & Zarigüeya común & 14 & $8.6 \%$ \\
\hline Notosciurus granatensis & Ardilla de cola roja & 16 & $9.9 \%$ \\
\hline Momotus aequatorialis & Barranquero & 1 & $0.6 \%$ \\
\hline Total & & 31 & \\
\hline \multicolumn{4}{|c|}{ Heliodora $2($ sampling nights $=162$, May 9 to October 27,2018$)$} \\
\hline Didelphis marsupialis & Zarigüeya común & 28 & $17.3 \%$ \\
\hline Notosciurus granatensis & Ardilla de cola roja & 11 & $6.8 \%$ \\
\hline Cerdocyon thous & Zorro cangrejero & 2 & $1.2 \%$ \\
\hline Rupornis magnirostris & Gavilán pollero & 1 & $0.6 \%$ \\
\hline Total & & 42 & \\
\hline
\end{tabular}

Opossum records $=$ number of nights when the species was observed (not the number of opossum records per night-see data analyses section).

Its avoidance is immediate, no learning is required, and adaptation to learn its avoidance is minimal(Mason, 1998; Osborn andParker,2002). Further toxicity effects on animals are unknown.

On the other hand, although citronella is mainly used as mosquito repellent (Muller et al., 2009), finding that it does not repel opossums supports the thesis that irritants are effective within some taxa (insects), but rarely among others (mammals or birds) (Mason, 1998). In addition, citronella is used as a fragrance ingredient in cosmetics, and it has antibacterial, antifungal and antiparasitic properties (Sharma et al., 2019; Kamal et al., 2020) that seem desirable rather than unpleasant.
An important question is whether opossums could get habituated to chemical repellents. Previous studies have shown that mammals can get habituated to pungent chemicals, such as wolverines (Gulo gulo) to lambs carrying a mixture of olfactory aversive oils in a dispenser attached to the neck and ear-tags. This result however was observed when wolverines did not have untreated lambs as an alternative prey (Landa et al., 1998; Landa and Tømmerås 2015; Smith et al., 2000). Whether opossums can get used to ammonia or creolin would need to be properly tested. Meanwhile, if chemical repellents are to be used, it would be advisable to use them only when really needed and not as a preventive measure for long periods of time. 
Finally, the wildlife diversity recorded in our study was known already in Envigado and the Área Metropolitana (Alcaldía de Envigado, 2018). The urban park held lower species richness, but opossums were relatively more common in comparison to the natural forest. This was expected given that opossums are highly unselective in their food habits and may take advantage from any resources (McManus 1970), including trash cans in urban parks (personal communication from park rangers). They also have been reported in diverse environments associated to humans, such as crops and roads (Orjuela and Jiménez 2004). This finding is rather important because opossums may have been underestimated in their ecological role in urban environments as evidenced by the current human-opossum conflict going on in Antioquia province(FUNDZAR personal communication). It is common species -not species richness- the ones expected to shape the environment by having more interactions with other species and the habitat itself (Gaston, 2010; Winfree et al., 2015). Populations of common species may decline because they are the first to suffer from any pressure on biodiversity (Gaston, 2010), and even more serious is the case of species in direct conflict with humans. Thus, future studies to monitor opossum abundance are desirable.

In conclusion, ammonia and creolin have the potential to repel opossums. Citronella, on the other hand, had no effect on reducing the number of opossum visits. These chemicals were tested in natural habitats, thus next they should be tested on real human-opossums conflict scenarios to probe their repellent potential. However, caution is warranted given its irritant, flammable, and corrosive properties. Nonetheless, we suggest that any management action to improve the welfare of mistreated opossums should be accompanied by education so we, humans, learn to value and cohabit peacefully with synanthropic wildlife.

\section{Declarations}

\section{Acknowledgments}

We thank the veterinary medicine undergraduate students who helped during the field work, particularly J.C. Montoya-Díaz and A.O. Arroyave-Pérez.

\section{Funding}

This study was partially funded by a scholarship granted to K.R and D.A. by the Facultad de Ciencias Agrarias and the Comité Para el Desarrollo de la Investigación (CODI) of Universidad de Antioquia (Convocatoria de proyectos de investigación en los programas de pregrado 2017, Acta 97, January 22, 2018), and the GAMMA research group of Universidad de Antioquia.

\section{Conflicts of interest}

The authors declare they have no conflicts of interest with regard to the work presented in this report.

\section{Authors contributions}

KN Rodríguez and DR Aguirre conceived the study, collected field data, and wrote the final report. CP Ceballos conceived the experimental design, administered the project, performed the statistical analyses, and wrote the manuscript.

\section{References}

Agency for Toxic Substances and Disease Registry ATSDR. Toxicological profile for ammonia. U.S. Department of Health and Human Services, Public Health Service, Atlanta, GA; 2004. 1-6 p. [access date: August 22, 2021] URL: https://www.atsdr.cdc.gov/toxprofiles/tp126.pdf

Alcaldía de Envigado. Plan de Desarrollo 20162019. 2016. [access date: August 16, 2021] URL: https://www.envigado.gov.co/pot/paginas/ contenido/programas-y-politicas/programa-1 
Alcaldía de Envigado. Informe final del SILAPE; 2018. [access date: August 22, 2021] https://www.envigado.gov.co/planeacion/ SiteAssets/010 A CORDEONES/ DOCUMENTOS $/ 2018 / 09 /$ Informe final Silape.pdf

Borden JH. Semiochemicals and bark beetle populations: Exploitation of natural phenomena by pest management strategists. Holarctic Ecol 1989; 12(4): 501-510. https://www.jstor.org/stable/3682061

Brown WL, Eisner T, Whittaker RH. Allomones and kairomones: transspecific chemical messengers. Bioscience 1970; 20 (1): 21-22. https://doi.org/10.2307/1294753

Delgado CA. Muerte de mamíferos por vehículos en la vía del Escobero, Envigado (Antioquia), Colombia. Actual Biol 2007; 29(87): 229-233. https://revistas.udea.edu.co/index.php/actbio/ article/view/329342

Elmeros M, Winbladh JK, Andersen PN, Madsen AB, Christensen JT. Effectiveness of odour repellents on red deer (Cervus elaphus) and roe deer (Capreolus capreolus): a field test. Eur J Wildl Res 2011; 57(6): 1223-6. https://doi.org/10.1007/s10344-011-0517-y

Flórez-Oliveros FJ, Vivas-Serna C. 2020. Zarigüeyas (Chuchas Comunes) Marmosas y Colicortos. Fundación Zarigüeya - FUNDZAR, Medellín, Colombia. p. 49-50. [access date: September 2, 2021] URL: https://www.metropol. gov.co/libro-zarigueyas

Gaston KJ. Valuing common species. Science 2010; 327(5962): 154-155. https://www.science. org/doi/10.1126/science. 1182818

González-Caro S, Vásquez A. Estado de los bosques de Antioquia entre 1990-2015. In: Quintero-Vallejo E, Benavides AM, Moreno N, González-Caro S, editors. Bosques Andinos, Estado Actual y Retos para su Conservación en Antioquia. Medellín, Colombia: Fundación Jardín Botánico de Medellín Joaquín Antonio Uribe - Programa Bosques Andinos (COSUDE).
2017; p. 63-80. [access date: September 22, 2021] URL: http://www.bosquesandinos.org/ wpcontent/uploads/2018/01/Libro_Bosques Andinos Interactivo.pdf

Guerisoli MM, Pereira JA. Deer damage: A review of repellents to reduce impacts worldwide. J Environ Manage 2020; 271: 110977. https://doi.org/10.1016/j.jenvman.2020.110977

Kamal HZ, Ismail TN, Arief EM, Ponnuraj KT. Antimicrobial activities of citronella (Cymbopogon nardus) essential oil against several oral pathogens and its volatile compounds. Padjajaran J Dent 2020; 32(1): 1-7. https://doi.org/10.24198/pjd.vol32no1.24966

Hunt, C. (1984). Behavioral responses of bears to tests of repellents deterrents and aversive conditioning. MSc Thesis, University of Montana; 1984. 136 p. [access date: December 2, 2021] URL: https://scholarworks.umt.edu/cgi/ viewcontent.cgi? article $=8081 \&$ context $=$ etd

Landa, A., \& Tømmerås, B. Å. Do volatile repellents reduce wolverine Gulo gulo predation on sheep? Wildlife Biol 1996; 2(3): 119-126. https://doi.org/10.2981/wlb.1996.041

Landa, A., Krogstad, S., Tømmerås, B. Å., \& Tufto, J. 1998. Do volatile repellents reduce wolverine Gulo gulo predation on sheep? Results of a large-scale experiment. Wildlife Biol 1998; 4(2): 111-118. https://doi.org/10.2981/wlb.1998.008

Mason JR. Mammal repellents: options and considerations for development. In: Proceedings of the Vertebrate Pest Conference 1998 (Vol. 18, No. 18). https://doi.org/10.5070/V418110271

McCrum-Gardner E. Which is the correct statistical test to use? $\mathrm{Br} \mathrm{J}$ Oral Maxillofac Surg 2008; 46(1): 38-41. https://doi.org/10.1016/j.bjoms.2007.09.002

McManus JJ. 1970. Behavior of captive opossums, Didelphis marsupialis virginiana. Am Midl Nat 1970; 84(1): 144-169. https://doi.org/10.2307/2423733 
Müller GC, Junnila A, Butler J, Kravchenko VD, Revay EE, Weiss RW, Schlein Y. Efficacy of the botanical repellents geraniol, linalool, and citronella against mosquitoes. J Vector Ecol 2009; 34: 2-8. https://doi.org/10.1111/j.1948-7134.2009.00002.x

Norman DM, Mason JR, Clark L. Capsaicin effects on consumption of food by cedar waxwings and house finches. Wilson Bull 1992; 104(3): 549-51. https://www.jstor.org/stable/4163197

O'Connell-Rodwell CE, Rodwell T, Rice M, Hart LA.Livingwiththemodernconservationparadigm: ¿Can agricultural communities co-exist with elephants? A five-year case study in East Caprivi, Namibia. Biol Conserv 2009; 93(3): 381-391. https://doi.org/10.1016/S0006-3207(99)00108-1

Orjuela OJ, Jiménez G. Estudio de la abundancia relativa para mamíferos en diferentes tipos de coberturas y carretera, finca hacienda Cristales, área Cerritos - La Virginia, municipio de Pereira, departamento de Risaralda - Colombia. Univ Sci 2004; 9: 87-96. [access date: December 2, 2021] URL: https://revistas.javeriana.edu.co/index.php/ scientarium/article/view/5028

Osborn FV, Parker GE. Community-based methods to reduce crop loss to elephants: Experiments in the communal lands of Zimbabwe. Pachyderm 2002; 33: 32-38.

Redpath SM, Bhatia S, Young J. Tilting at wildlife: reconsidering human-wildlife conflict. Oryx. 2015; 49(2):222-5. https://doi.org/10.1017/S0030605314000799

Rueda MC, Ramírez GF, Osorio JH. Aproximación a la biología de la zarigüeya común (Didelphis marsupialis). Bol Cient Mus Hist Nat 2013; 17(2): 141-153. http://www.scielo. org.co/pdf/bccm/v17n2/v17n2a13.pdf

Sharma, R, Rao R, Kumar S., Mahant S, Khatkar S. Therapeutic potential of citronella essential oil: a review. Curr Drug Discov Technol 2019; 16(4): 330-339. https://doi.org/10.2174/15701638 $\underline{15666180718095041}$

Smith, T. S., Herrero, S., Debruyn, T. D., Wilder, J. M. Efficacy of bear deterrent spray in Alaska. J. Wild Manag 2008, 72(3), 640-645. https://doi.org/10.2193/2006-452

Srbek-Araujo, A. C., Chiarello, A. G. Influence of camera-trap sampling design on mammal species capture rates and community structures in southeasternBrazil.BiotaNeotrop2013;13,51-62. http://www.biotaneotropica.org.br/v13n2/en/ abstract?article+bn02013022013

Sunquist ME, Austad SN, and Sunquist F. Movement patterns and home range in the common opossum (Didelphis marsupialis). J Mamm 1987; 68(1): 173-176. https://doi. org/10.2307/1381069

Vaughan C S, Hawkins LF. Late dry season habitat use of common opossum, Didelphis marsupialis (Marsupialia: Didelphidae) in neotropical lower montane agricultural areas. Rev Biol Trop 1999; 47(1-2): 263-269.

Vearrier, D., Jacobs D, Greenberg MI. Phenol toxicity following cutaneous exposure to creolin $₫$ : A Case Report. J Med Toxicol 2015; 11: 227-231. https://doi.org/10.1007/s13181-014-0440-1

Winfree R, W. Fox J, Williams NM, Reilly JR, Cariveau DP. Abundance of common species, not species richness, drives delivery of a real-world ecosystem service. Ecol Lett 2015; 18(7): 626-35. https://doi.org/10.1111/ele.12424 